جامعـة نيويورك أبـوظـبي 世 NYU |ABU DHABI

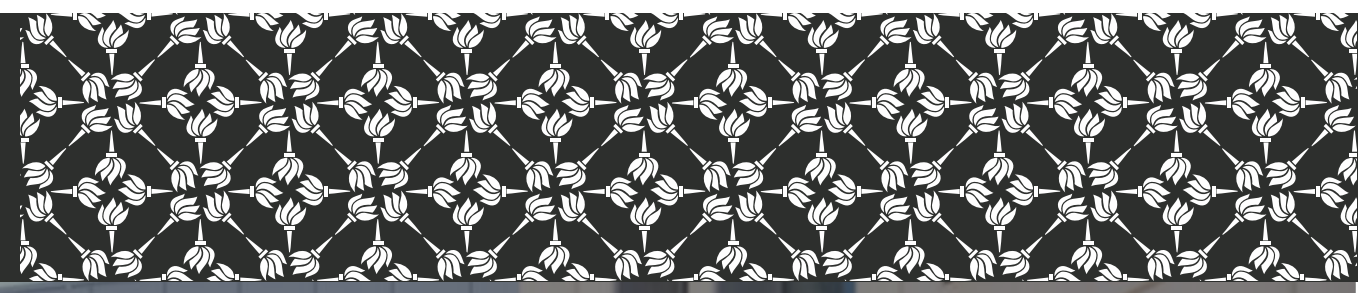

\title{
Real Wages Once More: A Response to Judy Stephenson
}

\author{
Robert C. Allen
}

Working Paper \# 0006

July 2017 
Real Wages Once More: A Response to Judy Stephenson

By

Robert C. Allen

Global Distinguished Professor of Economic History

New York University Abu Dhabi

Saadiyat Island

Abu Dhabi, United Arab Emirates

\author{
Senior Research Fellow \\ Nuffield College \\ New Road \\ Oxford OX1 1NF \\ United Kingdom
}

July 2017 


\begin{abstract}
Judy Stephenson's claim that institutional wage series like of those Greenwich Hospital overstate the earnings of building workers by $20-30 \%$ is examined, and, it is argued here, the conclusion is unpersuasive. Whatever adjustments to existing wage series are necessary in view of her new evidence would have no significant implications for real wages in England compared to the rest of the world. Consequently, Judy Stephenson's findings do not call into question the high wage high wage explanation of the Industrial Revolution.
\end{abstract}


Economists and historians have collected long time series of wages and prices for England, and these have been used to measure changes in the standard of living of workers. The original approach was simply to compare an index of wages to an index of prices (roughly weighted to reflect spending) to see if the resulting real wage ratio went up or down. ${ }^{1}$ More recent approaches have tried to extract more information from the data by estimating annual earnings and comparing them to the annual cost of subsistence. This method shows how far the standard of living was above or below subsistence, ${ }^{2}$ and it also facilitates international comparisons of living standards, which can be measured as the number subsistence baskets earned by workers in different countries. ${ }^{3}$ Serious questions arise in this research: How should the subsistence basket be defined? How are daily wages or servants' premiums ${ }^{4}$ converted to annual earings?

Judy Stephenson has added another issue to this list. ${ }^{5}$ She claims that the wage series for English building workers at least from the seventeenth century onwards overstate the earnings of the workers in view of changes in the organization of the building industry. Most of our information about builders' wages comes from the records of large institutions. In the middle ages, they hired workers, bought materials, and project managed themselves, so what they paid the workers was what the workers earned. After 1600, however, it was common for institutions to let contracts to builders who sometimes did the work themselves, sometimes hired tradesmen or labourers to do the job, and sometimes subcontracted work. In this period, the institutional records show what the institutions paid the contractors for labour, but the contractors kept some of that income for themselves and paid the workers less. That is Stephenson's thesis.

If she is right, then the estimates for England of the annual earnings and the implied number of baskets of subsistence goods that workers could consume are too high. This is important since it calls into question one of the important results of recent research on real wages, namely, the finding that the real wages of workers in eighteenth century England were high compared to the real earnings in many other parts of the world. This 'high wage' thesis, in turn, is important since it points to an economic explanation for the Industrial Revolution: it happened in England in the eighteenth century since high wages made it profitable to substitute capital for labour in production. Lower wages outside northwestern Europe meant that the incentive was lacking, and that is why mechanized technology was pushed forward in Britain but not elsewhere.

A key question is how much lower (if any) were the wages received by building workers compared to wages recorded in the institutional sources? This question would be

${ }^{1}$ Gilboy Wages, Phelps-Brown and Hopkins, 'Wages,' 'Consumables,' Perspective.

${ }^{2}$ Allen, 'European wages,' British industrial revolution.

${ }^{3}$ Allen, Murphy, and Schneider, 'Americas,' Allen, Bassino, Ma, Moll-Murata, and van Zanden, 'China,' Arroyo Abad, Davies, van Zanden, 'Spanish America,' Bassino and Ma, 'Japanese,' Broadberry and Gupta, 'Europe and Asia,' Frankema and van Waijenburg 'British Africa,' Özmucur and Pamuk, 'Ottoman Empire,' Pamuk and Shatzmiller, 'Middle East,'Plessis and Plessis, 'Cape,'Rönnbäck, 'Gold Coast,' Zwart, Globalization, Zwart and van Zanden, 'Java.'

${ }^{4}$ Humphries and Weisdorf, 'Women.'

${ }^{5}$ Judy Stephenson, 'Real wages.' 
hard enough to answer today with comprehensive and representative micro data from industrial censuses and household expenditure surveys. The problem is even more difficult for the eighteenth century, and historians must attempt to infer general patterns from incomplete information.

Stephenson has given various answers to the key question. At one point, she says that building contractors in the nineteenth century charged clients $20 \%$ more for labour than they paid their workers, and 'the eighteenth century worked on a similar basis.' In a later comparison with the Netherlands, she entertains the possibility that the discount was as much as 33\%: 'even if English silver wages were a third lower' ${ }^{6}$ Her data allow more precision in this matter and indicate, indeed, that the gap was much smaller.

Where do Stephenson's percentages come from? There are two bases. The first is her analysis of the costs of building contractors. They had overhead cost and 'normal' profits, which she estimates came to about one third of their labour and material costs. "Contractors would only have been able to recoup the administrative, finance and operating costs of their business, and anticipate discounting, if there was a margin between day rates charged to institutions and pay to workers."7 The numbers do not add up to support this claim, and, indeed, the commercial literature of the day points to different accounting procedures to generate the necessary revenues. The second basis of her case are the records she found of the wages actually paid to his employees by William Kempster, who was a mason and a contractor for masonry work at St Paul's cathedral. ${ }^{8}$ Payment records like this are highly unusual, so these data demand careful attention. Kempster's wages were lower than some series of institutional wage payments for the period, and that leads her to conclude that actual earnings were much below existing estimates. Again, the commercial literature of the period explains what was going on, and the differentials were much smaller than Stephenson claims. They do not threaten the high wage hypothesis.

Kempster's data and the high wage hypothesis

I begin with Kempster's wages and I accept them-on first pass-as indicative of what building workers 'really' earned. This assumption is provisional. There is an important issue about representativeness that must be considered, and that will be taken up later. We will see then that there is good reason to believe that most building workers 'really' earned more than the Kempster data show. I defer the argument about contractor's margins until the background is laid in the discussion of wages.

I focus on the Greenwich Hospital wages (as summarized by Schwarz ${ }^{9}$ since they are

${ }^{6}$ Ibid., p. 20, 22.

${ }^{7}$ Ibid., p 13.

${ }^{8}$ Stevenson discusses some other examples such as Bridge House, which had an eccentric payment system and a much smaller sample of wages than Kempster's payment records.

${ }^{9}$ Schwarz, 'London,' pp. 36-8. 
wages I used in support of the 'high wage' argument. ${ }^{10}$ The Greenwich series run from 1700 to 1860 . Boulton's series of London building wages run from 1574 to $1721 .{ }^{11}$ When they overlap in 1700-21, Boulton's, wages are considerably higher than the Greenwich wages, and I used the Greenwich wages so as not to overstate London's wage level.

An additional reason for concentrating on the Greenwich wage series is because they look representative of the London market for building labour. Warrant for this conclusion is that the Greenwich wages are consistent with wages given in price books, a growing genre in the eighteenth century. Price books helped people estimate construction costs. The favoured approach was to deconstruct a project into a list of standard tasks like building a rod of brick wall or constructing a door whose dimensions and features are precisely defined. The books indicated what each task should cost including labour, materials, profit, etc. The books were aimed at the consumers of construction, who did not want to be overcharged, and, increasingly, at builders to help them frame their bids. Charges based on these books were supposed to generate a satisfactory income for the builder as well as reducing disputes over bills. ${ }^{12}$

Thomas Wilsford's Archictectonice (1659) was the first book to present detailed costs of building projects. ${ }^{13}$ In the aftermath of the Great Fire, there was a boom in construction, which, no doubt, prompted some craftsmen to try their hands as contractors. Several price books offered them help. "In order...to give some light and insight into the Art of Building, unto such as are ignorant thereof, I have collected, and from the experience I have gained from conversing with Workmen, delivered such general Rules thereonto appertaining, that any person concerned can reap some benefit thereby, and be able (in some measure) to give a reasonable estimate of the Charge in the Erecting of such a Fabrick." 14 These early works did not go through many editions, but that changed in the eighteenth century. William Salmon (1701/2-1779) authored two series of price books, The Country Builder's Estimator and The London and Country Builder's Vade Mecum. The Estimator went through nine editions between 1733 and 1774, while the Vade Mecum went through five between 1745 and 1773. They were affordable. The first edition of the Estimator cost $1 \mathrm{~s} .6 \mathrm{~d}$. Both series contained unit costs for hundreds of standardized building projects.

In the 1770s the noted engraver Isaac Taylor (1730-1807) began publishing The Builder's Price-Book. This was continued by his son Josiah (1761-1834) and, after his death by other publishers. There were twelve editions between 1776 and 1800 and many afterwards. These books contain unit costs for hundreds of standardized building tasks. These books were also affordable. The 1776 edition cost $2 \mathrm{~s} 6 \mathrm{~d}$ and the price remained at that level until at least 1798. The 1823 edition cost 4 shillings reflecting the inflation of the French Wars. The price was less than a day's earnings for a carpenter or bricklayer.

${ }^{10}$ The data are on the London spreadsheet, wages page, columns F and G on my web page at https://www.nuffield.ox.ac.uk/People/sites/Allen/SitePages/Biography.aspx

\footnotetext{
${ }^{11}$ Boulton, 'London,' pp. 288-9.

${ }^{12}$ Langley, London prices, p. I.

${ }^{13}$ Campbell, 'Salmon.'

${ }^{14}$ Leybourn, Platform, p. 104.
} 
Competing titles were also on the market.

Price books frequently recorded the day wages of construction workers since that information was needed to work out the costs of particular tasks and because workers were hired by the day rather than by the task when work was not standardized. These day wages can be compared to the Greenwich wages. The correspondence is particularly close for building craftsmen. Figure 1 plots the wages of bricklayers and carpenters from price books with the Greenwich wage series I use for craftsmen. The series lie on top of each other, the only exceptions being when the Greenwich series underestimates the wages in the price books. The Greenwich series is a good summary of what builders charged clients for labour when day wages were paid.

What do the Kempster data show? They consist of 378 daily payments made to 'masons' in 1700-1701 and 362 payments to 'labourers.' There was considerable dispersion in daily wages. I will begin with the craftsmen since there is much more information about them that clarifies what was happening and since they accounted for two-thirds of the workers in the building industry. ${ }^{15}$ The frequency distribution of payments is bimodal. $23 \%$ of the payments were for $30 \mathrm{~d}$ per day and $35 \%$ were $24 \mathrm{~d}$ per day. $18 \%$ of the payments exceeded 30d. Stephenson surmises that these highly-paid workers were probably skilled carvers rather than ordinary masons. $7 \%$ of the workers earned $18 \mathrm{~d}-20 \mathrm{~d}$, which was the pay of a labourer. Why so little? Richard Jennings was also a contractor at St Paul's and testified in 1710 that he employed elderly and injured carpenters on the site since they could still do some useful work. ${ }^{16}$ It is likely that the low paid masons were similarly handicapped. $16 \%$ of the workers had an intermediate skill level earning between 24 and $30 \mathrm{~d}$ per day. The average of the 378 payments is $27 \mathrm{~d}$ per day. If we exclude the highly skilled and the low skilled, the average of the two modes and the intervening workers is still $27 \mathrm{~d}$ per day.

What is the significance of the two peaks? How was it that Kempster paid some masons $24 \mathrm{~d}$ per day, while he paid others 30d? Presumably the latter were more skilled, and, indeed, the two pay grades correspond to two widely recognized skill levels, namely, those of the master craftsman and the journeyman. Campbell's London Tradesman (1757) was a guide to help parents select an apprenticeship for their child, and it carefully distinguished the skills and the pay of masters and journeymen. Masters had the mental ability, education, and training to plan work as well as execute it. The journeyman's

skill consists, considering him as a mere Bricklayer, only in ranging his Brick even on top of another, and giving them their proper Beds of Cements; for it is suppos'd, the Architect directs him in everything relating to Dimensions. But a Master-Bricklayer thinks himself capable to raise a Brick House without the Tuition of an Architect: And in Town they generally know the just Proportions of Doors and Windows, the Manner of Carrying up Vents, and the other common Articles in a City-House. ${ }^{17}$

The low paid masons on Kempster's payroll were akin to the bricklayers who had the skill to

${ }^{15}$ Levi, Wages, p. 66. The figures relate to the middle of the nineteenth century.

${ }^{16}$ Carpenter, 'Finances, p. 333.

${ }^{17}$ Campbell, Tradesman, p. 159. 
lay the bricks straight and get the cement right, while the high paid men could do the complicated work.

Kempster's wage distribution lines up with Campbell's descriptions and both line up with the Greenwich Hospital wages. Campbell wrote in the middle of the eighteenth century when the wage level was about $6 \mathrm{~d}$ per day higher than it was in 1700 , the time of Kempster's data. Campbell says a journeyman bricklayer could expect to make $2 \mathrm{~s} 6 \mathrm{~d}$ per day and a 'foreman' 3s. Journeymen carpenters and joiners also made $2 \mathrm{~s} 6 \mathrm{~d}$ and masters $3 \mathrm{~s}$.

Subtracting 6d from each implies that the spike at 24d per day in Stepehenson's Figure 5 was the pay of a journeyman, while the spike at $30 \mathrm{~d}$ was the pay of a master craftsmen.

We can also compare these wages to the craftsmen's wages in the Greenwich Hospital series. In 1700, that wage was $30 \mathrm{~d}$ and in the 1750 s it was $36 \mathrm{~d}$ per day. The Greenwich Hospital series accurately tracks the wage of a master in Kempster's data and in Campbell's London Tradesman. In the case of the wage series I actually used, there is no $20-33 \%$ discount as Stephenson claimed. The only difference was for journeymen, and it was about $15 \%$. An average across both categories would yield an intermediate reduction of probably less than $10 \%$. A differential this small does not call the high wage hypothesis into question.

What about labourers? They made up about one third of the work force in the building industry. The Kempster data indicate that they were paid less than the Greenwich Hospital labourer series by about as much as the wage of a journeyman was discounted, namely, $18 \%$. What to make of this is not so clear, however. 'Labourer' conjures up an undifferentiated mass of skillless labour, but that vision is an illusion, for not all labourers were the same. In another important paper, Stephenson has argued that 'labourer' is a loosely defined concept covering many gradations of skill. ${ }^{18}$ This certainly was true of building labourers. Phillips tells us that in 1806 paviour's labourers were valued at 3s a day, bricklayer's, mason's, plasterer's, and slater's labourers at $3 \mathrm{~s} 6 \mathrm{~d}$, and plumber's labourers at $4 \mathrm{~s}{ }^{19}$ These rates presumably reflected skill, and the plumber's labourer was one third more productive than the paviour's. An assistant who knew the pace of building and how to time his deliveries to the needs of the bricklayer was much more valuable than someone with a strong back who did not know his way around a building site. In the case of craftsmen, we can situate Kempster's employees in a vocabulary of skills, but that is more difficult with the labourers since the language of skill is less refined with these workers.

While Campbell's London Tradesman describes mainly skilled trades, it also lists many jobs for labourers, and they were remunerated at different rates reflecting different skill levels. For instance, dyers of linen cloth employed calendarers to press the fabric. "Masters about Town employ Labourers, who earn from Nine to Twelve Shillings per Week, and by Degrees learn to be expert in the Business." ${ }^{20}$ Presumably it was the more expert who earned two shillings per day, the wage of a labourer at Greenwich Hospital. Likewise, brewers' labourers "have acquired their knowledge by experience" and sugar boilers' labourers "by degrees, learn the different Branches of" the business. In some cases, the wages of labourers ranged from 9 or 10 to 12 shillings per week. Presumably, those who had developed the skill earned Greenwich Hospital wage of two shillings per day. Tobacco cutters earned that wage,

\footnotetext{
${ }^{18}$ Stephenson, 'Pay.'

${ }^{19}$ Phillips, Crosby’s, pp. 50, 159, 169, 180, 185.

${ }^{20}$ Campbell, Tradesman, p. 262.
} 
and, indeed, labourers like coal haulers and glass grinders earned 12 - 15 shillings per week or more. ${ }^{21}$ From this perspective, the Greenwich Hospital series of labourers wages is not inconsistent with the range of labourers' wages in London.

The Greenwich Hospital series is also consistent with labourer's wages in London as quoted in price books (Figure 2). There was little difference in the wage levels other than the Greenwich wages being below those of the price books between Waterloo and the repeal of the corn laws.

In some cases, the rates in the price books are those paid by builders to their employees, and these rates match the Greenwich Hospital series and the earlier wages from Boulton that I incorporated into my series. ${ }^{22}$ Thus, Langley's The London prices of bricklayers materials and works (1750) worked out examples of charges for brick work and costed bricklayers at the customary 3 shillings per day and labourers at 2 shillings-the Greenwich Hospital rate. ${ }^{23}$ These rates were paid to the workers as they were prime costs. A century earlier, Primatt's The City \& Country Purchaser and Builder (1667) assumed that builders paid bricklayers and their labourers $36 \mathrm{~d}$ and $20 \mathrm{~d}$ per day, respectively, when he drew up his costings. ${ }^{24}$ These are the same as the London wages in my series, so the deductions implied by the Kempster data do not always obtain. This is not surprising since Kempster's data represent the experience of a single firm.

Setting that point aside, even the $18 \%$ reduction in labourer's wages suggested by Kempster's data is not enough to confute the high wage hypothesis, as we will see.

\section{Contractor's margins}

Stephenson's first argument for a large difference between the wage that a contractor billed a client and what was paid to the worker was indirect and depended on her estimate of overhead costs and normal profits. They came to about one third of labour and material costs. This is the only argument she offers that generates a number as large as one third. Since she claims that the difference between wages charged and wages paid might be that high, we should consider the argument carefully.

Suppose that Stephenson is right that overheads and normal profits came to $30 \%$ of the cost of labour and materials. ${ }^{25}$ The first thing to notice is that those items would not be covered by a $30 \%$ differential between the wage charged to client and paid to workers.

Suppose that the labour $\operatorname{cost}^{26}$ of a build was $£ 50$ and the material cost $£ 50$, so overhead costs

${ }^{21}$ Ibid., pp. 106, 173, 262-4, 273, 319.

${ }^{22}$ Boulton, 'London,' p. 279.

${ }^{23}$ Langley, London prices, p. 84.

${ }^{24}$ Primatt's City \& Country, p. 54.

${ }^{25}$ Stephenson arrived at the $30 \%$ figure by ingeniously linking together diverse bits of information. The figure is questionable, however. The price books to be considered recommend lower mark-ups to cover the same costs, the implication being that Stephenson's $30 \%$ is an overestimate.

${ }^{26}$ In this example the labour is valued at the wage charged to the client. 
and normal profit came to $£ 30$ (30\% of $£ 100$ ). Paying the workers $30 \%$ less than the client was charged would cut costs by $£ 15$ (30\% of $£ 50)$, which is only half of what is needed. To generate the $£ 30$ needed to cover the overheads, the wage paid to workers would have to be cut by $60 \%$. Nobody thinks that happened.

Indeed, the situation was more extreme than this example suggests since labour amounted to much less than half of the cost of building in early modern England. Gregory King estimated the value of the houses and structures in England in 1688, and his calculations show labour coming to one sixth of the total and materials to five sixths. ${ }^{27}$ With these cost shares, a builder who paid his workers nothing would only save one sixth of the cost of the labour and materials and could therefore only cover half of the overhead costs that Stephenson identified. Something has gone very wrong.

Price books tell us what builders really did. Some of the books give examples of how their standard charges were arrived at, and those calculations indicate there were two sources of profit. The first, and less important, was the one Stephenson emphasized: The builder hired a journeyman at a journeyman's wage but charged the client for a master craftsman. This practice was widely discussed. In 1710 Richard Jennings, a contractor building St Paul's Cathedral was tried for fraud. One of the accusations was that he paid his workers less than he billed his client. He admitted this and defended himself with the claim that this was normal industry practice. ${ }^{28}$ So it seems to have been. Campbell's London Tradesman (1757, p. 161) explains how a master joiner "pays his journeyman generally half a crown a day; but in Piece or Jobbing Work charges Three Shillings to his Employer." 29 Three shillings was the daily wage of a master and of a craftsman in my Greenwich series in the mid-eighteenth century. The builder pocketed one sixth of the wage he charged. In the early nineteenth century, wages were twice as high as they had been in Campbell's day, but the percentage discount remained about the same. Elsam's Builders' Price Book (1827) recommended charging the client $6 \mathrm{~s} 6 \mathrm{~d}$ per day for a carpenter or joiner. "This charge is made under the impression of the Journeyman's wages being $5 \mathrm{~s} 6 \mathrm{~d}$ per day." ${ }^{30}$ The difference of $15 \%$ closely matches the pay discount for journeymen in the eighteenth century.

It should be noted that making money in this manner was quite specific: It only applied to the journeymen. It did not apply to the masters. In the case of the master, the client was charged the master's wage and that was what the master earned. Indeed, that is what Kempster's data show. Differential charging did not apply to labourers either. They did not have two skill categories to be exploited in this way. Profit was made on payments to labourers in the same way it was made on materials, as we next consider.

The second source of surplus was much more important-namely adding a surcharge of about $20 \%$ to the total cost of materials and labour, the latter valued at the wage charged the client. Langley recommended a surcharge of $12.5 \%-25 \%$ to recoup the overhead costs that Stephenson discussed.

\footnotetext{
${ }^{27}$ King, 'Ms. book,' p. 246.

${ }^{28}$ Campbell, 'Finances,' p. 334.

${ }^{29}$ Campbell, Tradesman, p. 161.

${ }^{30}$ Elsam, Price Book, p. 48.
} 
By the real value of Materials, I don't mean the most Money that they may be sold for at any Time after having been used, or employed; but I mean such an Advance of Increase of Price above their Prime Costs which is reasonable, that every Master should be paid, for the Interest of the Monies laid out; for his Warehouse -Room, \&c. and for his Time, Expenses, and Trouble to buy in, to attend Gentlemen, \&c. which when sold in small Quantities for Repairs, as likewise for Day-Workmen's Labour, is honestly worth 25 Per Cent. But for Materials sold in large Quantities for new Works, Twelve and a Half per Cent. is a sufficient HONEST GAIN. ${ }^{31}$

Langley gives many examples of calculating these surcharges. ${ }^{32}$ They are added to the costs of labour and materials in order to get the price to bill the client. The aim was never to work out a higher daily wage in the manner Stephenson supposes. Instead, Langley worked out the cost per unit (eg per rod of wall one and half bricks thick) which was the form in which the client was billed.

This form of accounting continued to be used in the nineteenth century. In Elsam's example of working out a price, "Eleven shillings and two-pence half penny, therefore, is the exact value of the materials, which includes 20 per cent. profit; to which sum must be added, the prime cost of the average labour, with a reasonable profit thereon," ${ }^{33}$ which also equalled $20 \%$.

The surcharge brought in more money than the fiddle with wages. The relative importance of the two sources of profit depended on the magnitude of the surcharge and the share of labour in the combined labour and material costs of the building. If a project cost $£ 100$ in labour and materials, then a 20\% surcharge would bring in $£ 20$ to cover overheads and profit. If we take Stephenson's most extreme formulation that workers were paid one third less than clients were billed and adopt King's view that labour came to one sixth of costs, then the profit generated by this manoeuver would have been $£ 511 \mathrm{~s} 1 \mathrm{~d}=1 / 3 * 1 / 6 *$ $£ 100$. The surcharge dwarfs the income generated by 'underpaying' the worker. A more realistic wage difference would make the latter almost inconsequential. Since this fiddle brought in so little compared to the $20 \%$ surcharge, we cannot accept Stephenson's claim that "contractors would only have been able to recoup the administrative, finance and operating costs of their business, and anticipate discounting, if there was a margin between day rates charged to institutions and pay to workers." All the builder had to do was set the appropriate surcharge. By the same token, the magnitude of the overhead costs and normal profits had no bearing whatsoever on the difference, if any, between the wage charged to the client and the wage paid to the worker.

\section{payment system unrepresentative}

\footnotetext{
${ }^{31}$ Langley, London prices, p. iv.

${ }^{32}$ Langley, London prices, gives many examples of calculating these surcharges (e.g. p. 84).

${ }^{33}$ Elsam, Price book, p. 14. Cf. Taylor's Builder's price book, pp. 71, 72, 80, 81, for instance, that show mark ups of $15 \%$ or $20 \%$ on labour and material costs. See also Powell, Building industry, p. 28.
} 
Stephenson's analysis of contractor's margins does not establish the differential between the day rates charged to clients and the money received by workers. Kempster's data show that the differential was smaller than she claimed. There is good reason, moreover, to believe that the differential was smaller still, and that is because Kempster's pay records are not representative of normal forms of contract in the building industry.

There were three forms of contract between clients and builders. Either a total price for the whole job was agreed, or builders were paid on a piece rate system, or they billed the client for days of work plus the cost of materials. The second was the most common and was regarded as the most cost effective. Billing for days worked plus material costs was only used for non-standardized jobs, and fixed quotations for a whole project were rare. Likewise, there were two forms of contract between contractors and their employees. When the contractor was paid on a piece rate system, he paid his worker in the same way but at a lower rate than he received from the client. The worker was paid by the day only when the contractor was paid by the day, and, as with the piece rate system, the client was billed at a higher rate than the worker (if a journeyman) was paid.

Daily wage payments as in the Kempster data set only resulted from the last form of contract, and this was very uncommon. Stephenson estimates that only 5-10\% of the total of days worked were paid by the day. ${ }^{34}$ Piece work was the norm. Why? The answer is simple. Piece rates incentivized the employees to work hard. So long as the increase in work done per day exceeded the increase in wage payment per day, the contractor's costs fell. Both the worker and the contractor came out ahead financially, so the labour market gravitated to this form of contract. Campbell explains how it worked. A joiner "sometimes lets out work to his Journeymen by the Piece or by the Yard, allowing him proportionally less than he charges himself," that is, the joiner pays the journeyman less than the client is charged. "Of these jobs an industrious Workman generally makes more than Day-Wages; perhaps, because he applies closer than if working for a Master." ${ }^{35}$ McKellar gives two examples of such pay scales. In the first, the builder charged the client $£ 510$ s for each rod of wall built but only paid the bricklayer $£ 55 \mathrm{~s}$ or $5 \%$ less. The second involved paying a tiler 20 s per square (10 feet by 10 feet) for which the client was charged $26 \mathrm{~s}$ ( $30 \%$ more) ${ }^{36}$ The contractor billed the client for work on a piece-rate basis and hired a worker to do the work at a lower piece rate. By pushing himself, the worker earned more than he could at the going daily wage. This means that Kempster's day wages understate what the great majority of building workers really earned. The gaps between the Greenwich wage series and the real earnings of building workers are even less than Kempster's data suggest.

The experience of the royal dockyards, to be discussed in the next section, provides a basis for quantifying the impact of the piece rate system on earnings. Building ships involved some of the same trades and many of the same skills as building houses, so the experience of the dockyards is relevant to the construction industry. Payment was always by the day until the second half of the eighteenth century when 'task work' was introduced.

Between 1805 and 1811 labourers paid by the piece earned 37\% more than those paid by the day. Between 1791 and 1811, ship wrights paid by the piece earned $23 \%$ more than those

\footnotetext{
${ }^{34}$ Stephenson, 'Real wages' pp. 9-10.

${ }^{35}$ Campbell, Tradesman, p. 161.

${ }^{36}$ McKellar, Building, p. 87.
} 
paid by the day, and between 1805 and 1811 that premium jumped to $41 \%{ }^{37}$ It would be no surprise if building workers earned one third more when paid by the piece rather than by the day. This increase would have swamped all of the differences in hourly rates documented by Stephenson and would mean that building workers in London actually earned more than the Greenwich Hospital wage rate.

\section{What about elsewhere in England?}

The evidence considered thus far relates to London. Stephenson thinks that the contracting system was common elsewhere in England, and that existing wage series are payments to contractors rather than to workers, so that wages should be discounted by the same $20-30 \%$ she thinks London wages should be reduced in order to estimate what building workers actually took home. She has no data like Kempster's for work outside of London to show what workers really earned (at least the minority employed on day wages), so the argument is conjectural.

There is evidence, however, of what one class of workers earned in southern England outside of London. The naval dockyards employed hundreds of building workers. ${ }^{38}$ The royal yards had to compete with private shipyards and the building trades for their workers. The payment system was extremely complicated. For much of the eighteenth century there was a daily wage rate, which had not changed since the late seventeenth century. In addition, overtime was paid as tides and nights, which were nominally 1.5 and 5 hours of additional work. Tides and nights were paid to get more work done during the frequent wars and to increase wages as prices rose in the eighteenth century. There were allowances for lodging somewhat offset by a charge for the chaplain. Workers were further rewarded by being allowed to take on apprentices for whom they were paid more than they passed on to the apprentice. Finally, workers had the right to take off-cuts called chips out of the yards and sell them-a privilege often abused. As the price level rose, the system came under strain. In the middle of the eighteenth century, piece rate payments were introduced. The Navy Board took this step reluctantly fearing that work quality would drop, and workers resisted it through strikes thinking they would have to do more work for no more pay. However, a satisfactory solution was finally achieved, so that wages rose, costs fell, and quality was maintained. The success of task work in raising earnings above day rates and cutting costs in ship building, an activity that employed many in the building trades, is further reason to accept that work by the piece in the building trades was in the interests of contractors and raised the incomes of building workers above the day rates of Kempster's employees.

It would be difficult for a historian to figure out what all of the sources of income came to, but the Naval Enquiry of 1806 made the effort at least for the Plymouth yard for many years. Figure 3 shows the average daily earnings of bricklayers and house carpenters employed in Plymouth. The Greenwich wage series for London craftsmen and the PhelpsBrown and Hopkins wage for craftsmen, which I use for southern England outside of the capital, are also shown. The latter is the most pertinent for comparison with Plymouth. The

${ }^{37}$ Morriss, Dockyards, p. 103.

${ }^{38}$ Ehrman, Navy, Baugh, Administration, Morriss, Dockyards, Knight, Portsmouth, pp. xli-xlviii. 
carpenters usually earned more than the bricklayers but both dockyard series lie not only above the southern England series but also above the London series in many years.

We can make similar comparisons for labourers in Plymouth (Figure 4). There were two grades of labourer. The scavelmen were a group selected out of the pool of general labourers, and they earned more than the remaining labourers. This is the kind of distinction in grades of labourer than we encountered before, and it would be very helpful to know how the Greenwich labourers and Kempster's labourers compared to the scavelmen and the remaining dockyard labourers, but that information is not at hand. Be that as it may, the scavelmen always earned more than the Phelps-Brown and Hopkin's series of labourers' wages, and the remaining dockyard labourers normally did so as well. The earnings of scavelmen often exceeded the earnings of Greenwich labourers.

Based on the record of the naval dockyards, there is no reason to believe that PhelpsBrown and Hopkins wage series understate the take-home pay of building workers in southern England.

\section{What about Europe, Asia and the High Wage Hypothesis?}

The high wage hypothesis is meant to apply across nations and, indeed, continents. In previous work, I showed that real wages across Europe were similar in the fifteenth century, but they diverged thereafter as wages fell across most of the continent under the pressure of an expanding population, while they were maintained in England and the Dutch cities as their maritime economies boomed. ${ }^{39}$ This mattered for explaining the Industrial Revolution, since the high wages in Britain increased the incentive to adopt labour saving machinery. This argument, evidently, cannot explain why the Industrial Revolution did not happen in the Netherlands-that was down to their free trade policy which meant that they imported cotton textiles rather than making them by hand, so they had no cotton industry to mechanize, and to the political obstacles to developing Ruhr coal, which was the counterpart to the coal in northern England-but it throws light on why cotton production was not mechanized on the European continent or in large handicraft industries in India and China. How do reductions in English wages like those suggested by Kempster's data affect this argument?

Figure 5 shows the evolution of building craftsmen's wages in London and four European cities. Annualized wages are normalized by the cost of a family's subsistence to highlight how well people were doing. The sixteenth century divergence is striking. Figure 5 shows two series for London. One uses my original Greenwich craftsmen's series, and the second reduces that by $9 \%$ after 1600 to show how average earnings for masters and journey paid by day work might have been affected by the contracting system. The two London lines are so close together that the choice between them is of no consequence. The fact that most craftsmen were paid by the piece and would have earned more than is shown by the discounted line is ignored.

Figure 6 performs a similar exercise for building labourers incorporating data for Delhi and Beijing. A discount of $18 \%$ is applied to the London building wages. This is the value consistent with Kempster's data. Again there is a great divergence, although it begins later when London wages are reduced. As with the craftsmen, no upward adjustment has been made for the increased earnings of piece work, so Figure 6 overstates the impact of the

\footnotetext{
${ }^{39}$ Allen 2001, 2003, 2009, 2017)'European wages,' 'Poverty,' British industrial revolution, Industrial revolution.
} 
shift to contracting on the international comparisons.

Something else that is ignored in these figures is the likelihood that similar adjustments might be in order elsewhere. The Netherlands is the obvious case in point, but comparisons are not so simpler. On the one hand, as Stephenson points out, the Dutch wages are averages from the records of employers in Amsterdam and other cities in the western Netherlands. ${ }^{40}$ The employers are generally public institutions. As such, they are comparable to Greenwich Hospital and the Royal Dockyard in Plymouth. Hence, no adjustment should be made to the Greenwich series in comparisons with Amsterdam. On the other hand, in the private sector, building contractors like those in England were common. For instance, Prak describes how stone masons had construction firms from the sixteenth century onwards with the Van Traa being a particular example. "During the three centuries covered by this chapter, they [stone masons] were in charge of major building projects." Carpenters and bricklayers also had firms that sound remarkably like those in London. "Carpenters usually acted as the master builders...some firms were actually capable of undertake substantial projects. Especially Amsterdam builders were active in a large area, which also included the countryside of North-Holland."41 In that case, perhaps the Amsterdam wages require similar adjustments to those for London when compared with other parts of the world..

It would be surprising, indeed, if London were different from Amsterdam in its contracting system. Goldthwaite has described incipient building firms in renaissance Florence. ${ }^{42}$ Craftsmen were coming forward there to manage projects. They were more like supervisors than independent contractors, however, for they lacked the capital to finance the projects. They could not do what contractors in London did, namely, hire workers and buy materials and then wait a long time to be paid. The clients in Florence had to pay their builders frequently to keep their businesses liquid. Here Stephenson's analysis of contractors margins comes into it own, for she shows that the interest costs of financing their businesses were substantial. The high incomes in seventeenth and eighteenth century London allowed craftsmen to accumulate capital and make the move up to contractors. The Dutch Republic was another high wage economy and awash in capital, so it would be expected that the organization of the building industry would evolved along a similar trajectory.

\section{$\underline{\text { Conclusion }}$}

Judy Stephenson has enlivened the history of wages with her discovery of the Kempster material, and her research has brought to the fore aspects of the labour market that have not previously received attention. She has opened up the important question of why building contractors emerged in the seventeenth century and advanced our understanding of how they framed their bids and organized their workers. She has probed the nature and extent of 'skill' among the so called 'unskilled,. This is an important issue, and, I suspect, it has a lot further to run. None of these achievements, however, calls the high wage hypothesis into question.

\footnotetext{
${ }^{40}$ Stephenson' Real wages,' p. 21.

${ }^{41}$ Prak, 'Market, pp. 53-4, 55, 59.

${ }^{42}$ Goldthwaite, Florence, pp. 115-70.
} 
Figure 1

Source:

Craftsmen's wages: Alternative series

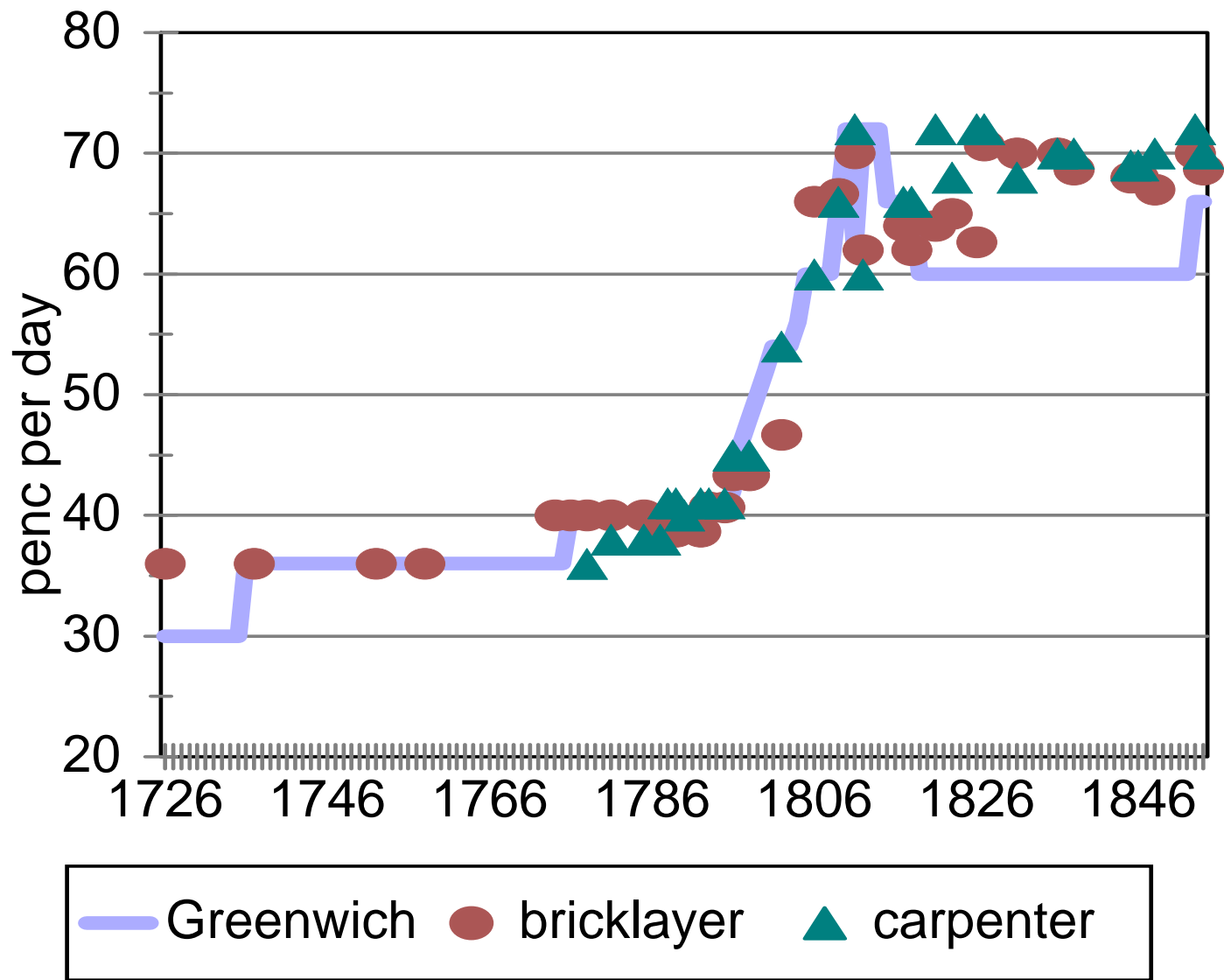

Greenwich-Column F of the London spreadsheet on Allen web page at https://www.nuffield.ox.ac.uk/People/sites/Allen/SitePages/Biography.aspx

Bricklayer and carpenter-

Neve, City and Country, 1736.

Langley, , London prices, 1748, 1749, 1750.

Builder's price-book, 1774, 1776, 1781, 1785, 1787, 1788, 1789, 1792, 1793, 1795, 1796, 1798, 1802.

Pain, British palladio.

Skyring, Z, Builders' prices, 1812, 1818, 1826, 1827.

Skyring, H.W., Builders' prices, 1831, 1836, 1838, 1845, 1846.

Bowley, Wages, pp. 82-3.

Note: when separate rates for Lord Mayor's Day to Lady Day and Lady Day to Lord Mayor's Day were reported, a weighted average reflecting the number of days in each period was calculated. 
Figure 2

Source:

Building Labourers' Wages: Alternative Series

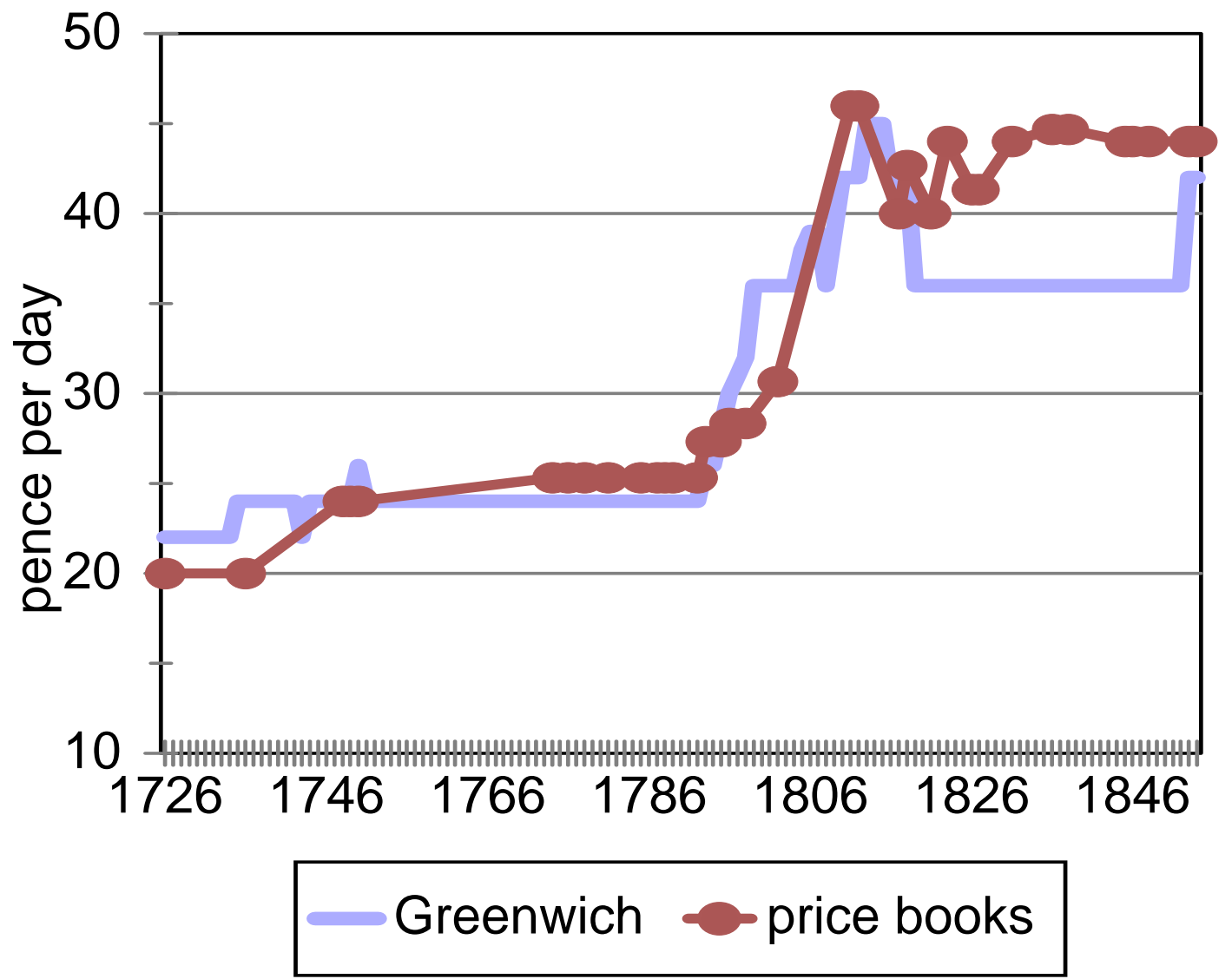

Greenwich-Column $\mathrm{G}$ of the London spreadsheet on Allen web page at https:/www.nuffield.ox.ac.uk/People/sites/Allen/SitePages/Biography.aspx price books-same as Figure 1. 
Figure 3

Craftsmen's pay in Plymouth Naval Dockyard

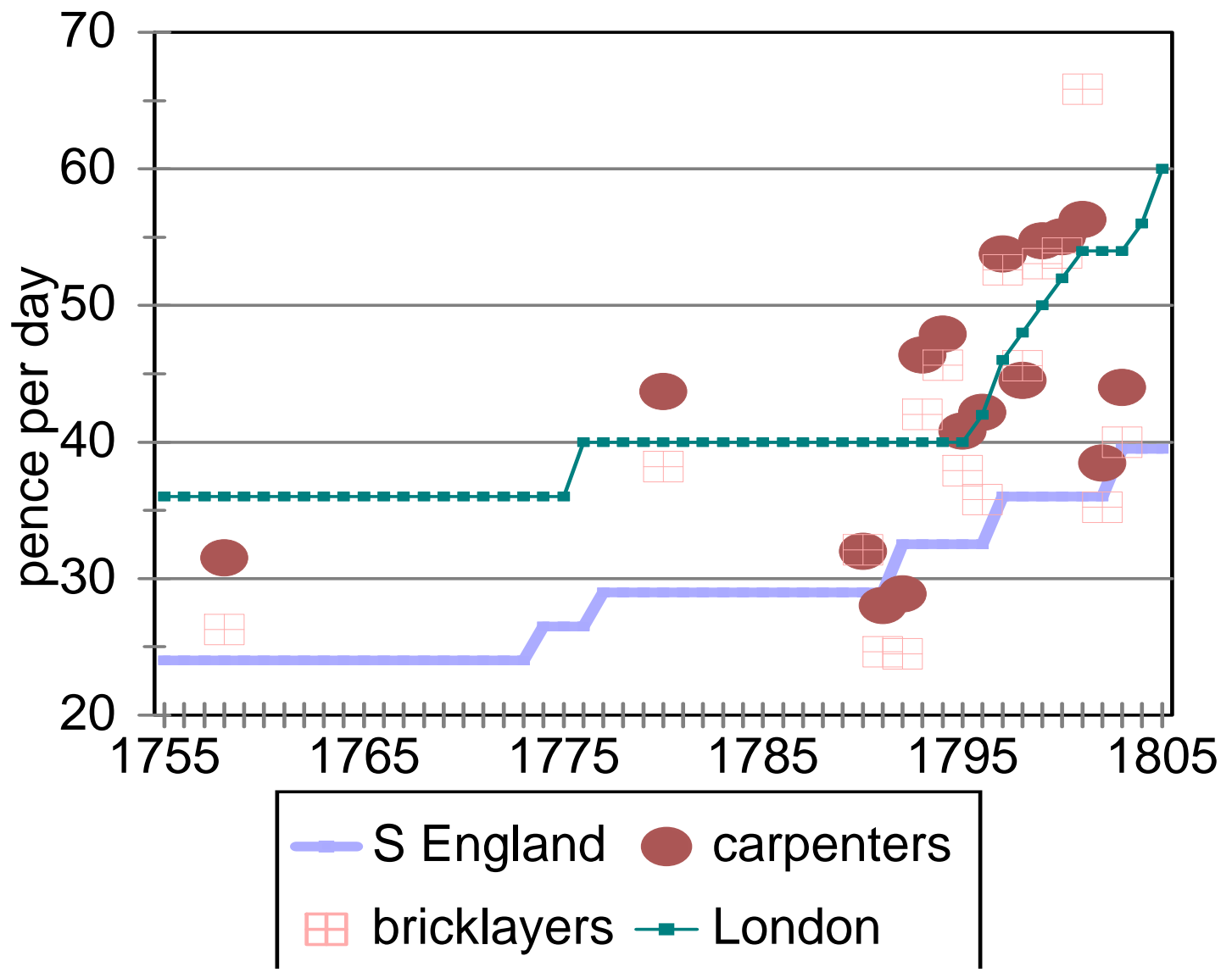

sources:

southern England and London--Columns C and F of the London spreadsheet on Allen web page at https://www.nuffield.ox.ac.uk/People/sites/Allen/SitePages/Biography.aspx

carpenters-Sixth Report, p. 373, gives total wages paid in the year and average number of men. Daily wage computed as total wages divided by number of men at 313 days worked per year. This is the Enquiry's standard procedure (cf. p. 89).

bricklayers- same procedure as carpenters with data from Sixth Report, p. 374. 
Figure 4

Labourers' Pay in Plymouth Naval Dockyard

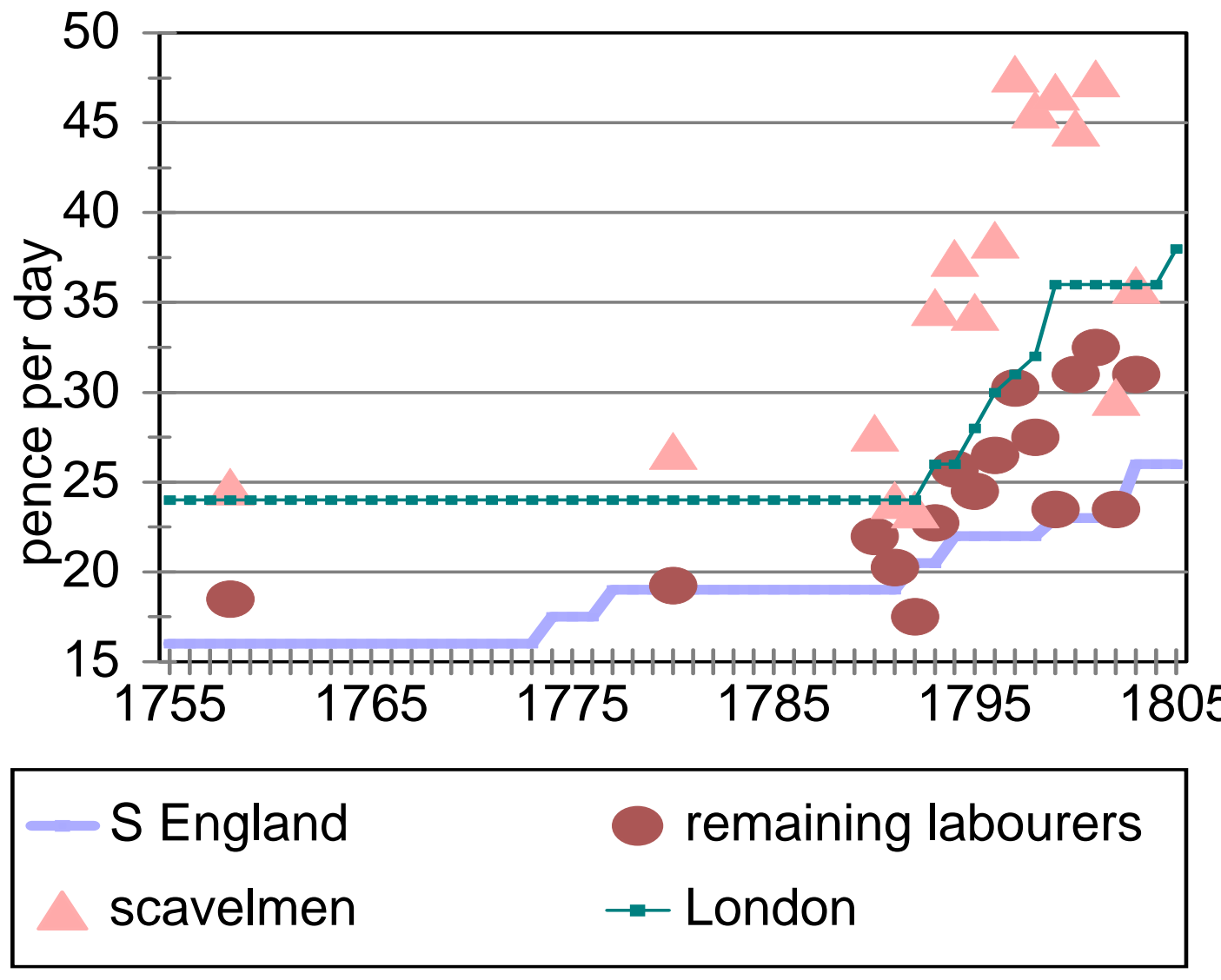

sources:

southern England and London--Columns D and G of the London spreadsheet on Allen web page at https://www.nuffield.ox.ac.uk/People/sites/Allen/SitePages/Biography.aspx

scavelmen and remaining labourers- Sixth Report, p. 89. 
Real wages of building craftsmen

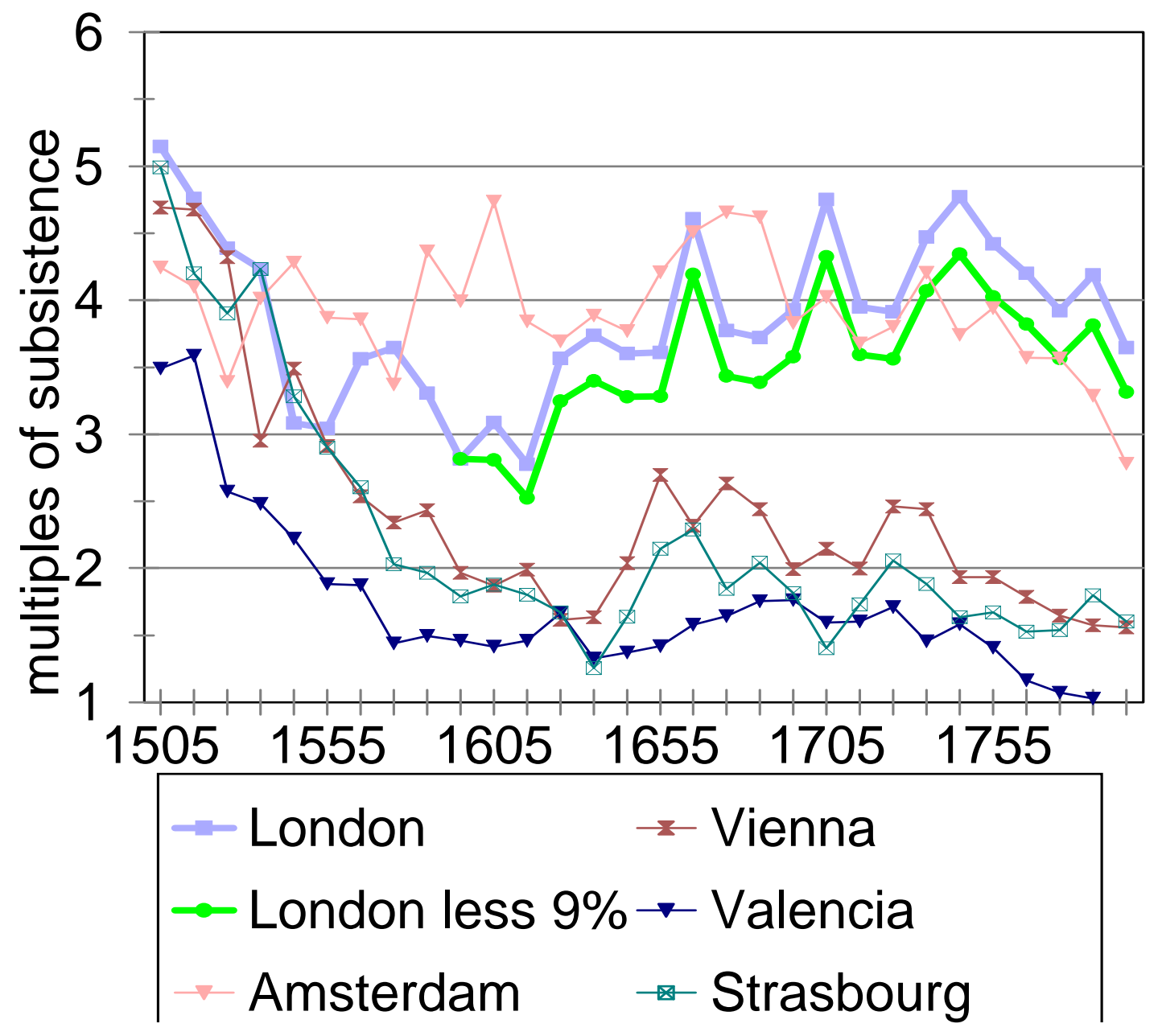


Figure 6

Real wages of building labourers

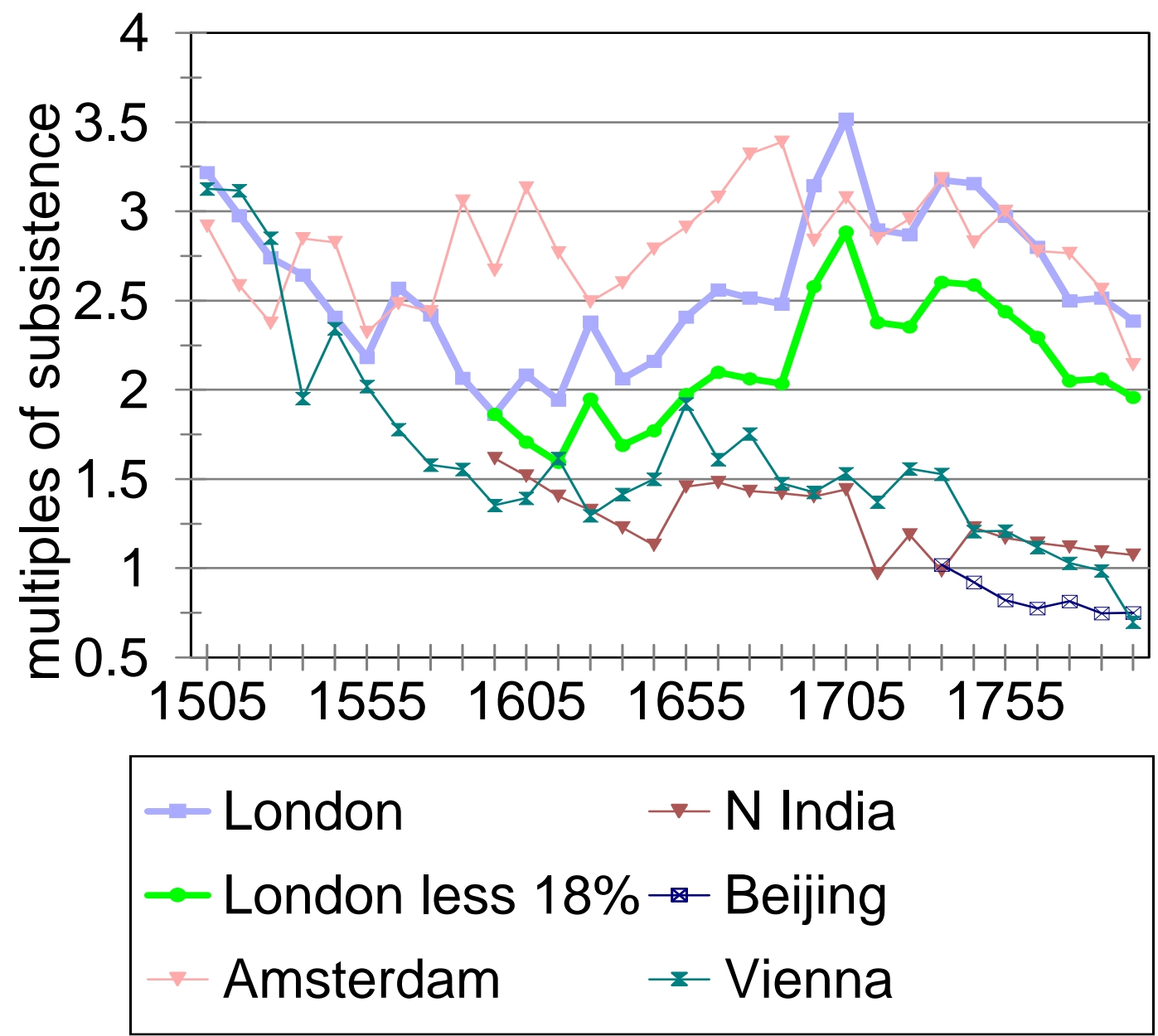




\section{$\underline{\text { References }}$}

Allen, Robert C., "The great divergence in European wages and prices from the Middle Ages to the First World War," Explorations in Economic History, 38, (2001), pp 411-447.

Allen, Robert C.. "Poverty and progress in early modern Europe," Economic History Review, LVI, (2003), pp. 403-443.

Allen, Robert C., The British industrial revolution in global perspective, (Cambridge, 2009).

Allen, Robert C., The industrial revolution: a very short introduction, (Oxford, 2017).

Allen, Robert C., Bassino, J.-P., Ma, D., Moll-Murata, C., and van Zanden, J.L., "Wages, prices, and living standards in China,1739-1925: in comparison with Europe, Japan, and India," Economic History Review, 64, (2011), pp. 8-38.

Allen, Robert C., Murphy, T., and Schneider, E., "The colonial origins of divergence in the Americas: a labour market approach," Journal of Economic History, 72, (2012), pp. 863894.

Arroyo Abad, Leticia, Davies, Elwyn, and van Zanden, Jan Luiten, "Between conquest and independence: real wages and demographic change in Spanish America, 1550-1820," Explorations in Economic History, 49, (2012), pp. 149-66.

Babbage, Charles, On the economy of machinery and manufactures, (1832).

Bassino, Jean-Pacal, and Ma, Debin, "Japanese unskilled wages in international perspective, 1742-1913," Research in Economic History, 23, (2006), pp. 229-48.

Baugh, D.A., British naval administration in the age of Walpole, (Princeton, 1965).

Boulton, Jeremy (1996). "Wage labour in seventeenth-century London," Economic History Review, XXXXIX, (1996), pp. 268-90.

Bowley, Arthur L., Wages in the United Kingdom in the nineteenth century, (Cambridge, 1900).

Braverman, Harry, Labor and monopoly capital, (New York, 1974).

Broadberry, Stepehn, and Gupta, Bishnupriya, "The early modern great divergence: wages, prices and economic development in Europe and Asia, 1500-1800," Economic History Review, 59, (2006), pp. 2-32.

Campbell, J. W. P. , 'Salmon, William (1701/2-1779)', Oxford dictionary of national biography, Oxford University Press, 2004 [http://www.oxforddnb.com/view/article/24560, accessed 15 Sept 2017]

Campbell, James W.P. (2005). "The finances of the carpenter in England 1660-1710: a case 
study on the implications of the change from craft to designer-based construction", in Simonetta Cavaciocchi, ed., L'Edilizia Prima della Rivoluzione Industriale, Secc.XIII-XVIII, (Prato, 2005), pp. 313-346

Campbell, R. The London tradesman, (1757).

Crossick, Geoffrey, An artisan elite in Victorian society, (1978).

Dyos, H.J., "The speculative builders and developers of Victorian London," Victorian Studies, 11, (1968), pp. 641-690.

Elsam, Richard, The practical builder's perpetual price-book, (1826).

Ehrman, J., The navy in the war of William III 1689-1697: its state and direction, (Cambridge, 1953).

Frankema, Ewout, and van Waijenburg, Marlous, "Structural impediments to African growth? New evidence from real wages in British Africa, 1880-1965," Journal of Economic History, 72, (2012), pp. 895-926.

Gilboy, E., Wages in eighteenth century England, (Cambridge, MA, 1935).

Goldthwaite, Richard A., The building of renaissance Florence: an economic and social history, (Baltimore, 1980).

Humphries, Jane, and Weisdorf, Jacob, "The wages of women in England, 1260-1850," Journal of Economic History, 75, (2015), pp. 404-447.

King, Gregory (1973). " $17^{\text {th }}$ century Ms. book of Gregory King," in Peter Laslett, ed., The earliest classics: John Graunt and Gregory King, (Farnborough, 1973).

Knight, R.J.B., Portsmouth dockyard papers 1774-1783: The American war, (Portsmouth, 1987).

Langley, Batty, The London prices of bricklayers materials and works [electronic resource], both of new buildings and repairs, justly ascertained: and the common exactions and abuses therein detected, (1748).

Langley, Batty, The London prices of bricklayers materials and works [electronic resource], both of new buildings and repairs, justly ascertained: and the common exactions and abuses therein detected. (1749).

Langley, Batty, The London prices of bricklayers materials and works, both of new buildings and repairs, justly ascertained. (1750).

Levi, Leone, Wages and earnings of the working classes, (1867).

Leybourn, William, A platform for purchasers, guide for builders, mate for measurers, 
(1668).

McKellar, Elizabeth, The building of modern London, (Manchester, 1999).

The measurer's mate : a story of builders' price-books during three centuries, (1960).

Morriss, R., The royal dockyards during the Revolutionary and Napoleonic Wars, (Leicester, 1983).

Neve, Richard, The city and country purchaser, and builder's dictionary [electronic resource]: or, the compleat builder's guide. ... By T. N. Philomath., (1703).

Neve, Richard, The city and country purchaser, and builder's dictionary [electronic resource]: or, the compleat builders guide. ... by Richard Neve, Philmath., (second edition, 1727).

Neve, Richard (1736). The city and country purchaser's and builder's dictionary [electronic resource]: or, the complete builder's guide. ... originally written and compiled by Richard Neve, Philomath, ( $3^{\text {rd }}$ edition, 1736).

Özmucur, Süleyman, and Pamuk Sevket, "Real wages and standards of living in the Ottoman Empire, 1489-1914,” Journal of Economic History, 62, (2002), pp. 293-321.

Pain, William, Pain's British palladio; or, The builder's general assistant, (1790).

Pamuk, Şevket and Maya Shatzmiller, "Plagues, wages, and economic change in the Islamic Middle East-1500,” Journal of Economic History, 74, (2014), pp 196-229.

Phelps Brown, E.H., and Hopkins, Sheila V., "Seven centuries of building wages," Economica, NS, 22, (1955), pp. 195-206.

Phelps Brown, E.H., and Hopkins, Sheila V., "Seven centuries of the prices of consumables, compared with builders' wage rates," Economica, NS, 23, (1956), pp. 296-314.

Phelps Brown, E.H., and Hopkins, Sheila V., A perspective of wages and prices, (1981).

Phillips, John, Crosby's builder's new price-book for 1807, (9 $9^{\text {th }}$ edition, 1878).

Plessis, Sophia du, and Plessis, Stan du, "Happy in the service of the Company: The purchasing power of VOC salaries at the Cape in the $18^{\text {th }}$ Century," Economic History of Developing Regions, 27, (2012), pp. 125-49.

Powell, C.G. An economic history of the British building industry, 1815-1979, (1980 ).

Prak, Maarten (2010). “The market for architecture in Holland, 1500-1815," in Laura Cruz and Joel Mokyr, eds., The Birth of Modern Europe: Culture and Economy, Leiden, (2010), pp. 35-59. 
Rönnbäck, K., "Living standards on the pre-colonial Gold Coast: a quantitative estimate of the African labourer's welfare ratios," European Review of Economic History, 18, (2014), pp. 185-202.

Salmon, William, The country builder's estimator, $(1733,1737,1752,1758,1759,1774)$.

Salmon, William, The London and country builder's vade mecum, $(1733,1748,1755,1760$, 1773).

Schwarz, L.D., "The standard of living in the long run: London, 1700-1860," Economic History Review, 2nd series, XXXVIII, (1985), pp. 24-41.

Skyring, Z., Skyring's builders' prices, (1812, 1818, 1826, 1827).

Skyring, W.H., Skyring's builders' prices, (1831, 1836, 1838, 1845, 1846).

Stephenson, Judy, "The pay of labourers and unskilled men on London building sites, 16601770," Cambridge Working Papers in Economic and Social History, no. 24 (2016).

Stephenson, Judy, “'Real' wages? contractors, workers, and pay in London building trades, 1650-1800," Economic History Review, (2017), pp. 1-26.

The Builder's price-book; containing a correct list of the prices allowed by the most eminent surveyors in London, to the several artificers concerned in building, (1774, 1776, 1781, $1785,1787,1788,1789,1792,1793,1795,1796,1798,1802)$.

Taylor's builder's price book : newly arranged : containing a correct list of prices allowed by the most eminent surveyors in London to the several artificers concerned in building : with the journeymen's prices affixed to each article : to which are added, a variety of important memorandums and tables ....also a copious abstract of the building act, (1823).

Wilsford, Thomas, Archictectonice, the art of building,; or an introduction to all young surveyors in common structures, (1659).

Zwart, Pim de (2016). Globalization and the colonial origins of the great divergence, (Leiden, 2016)

Zwart, Pim de, and zan Zanden, Jan Luiten,"Labor, wages and living standards in Java, 16801914," European Review of Economic History, 19, (2015), pp.215-34.

\section{Official papers}

Sixth Report of the Commissioners of Naval Enquiry: Plymouth Yard, Woolwich Yard, (P.P., 1803-4, III). 